\title{
VAN KARNAK TOT KAKAMAS: DIE NALEEF VAN OU EGIPTE IN DIE SUID-AFRIKAANSE BOUKUNS ${ }^{1}$
}

\author{
I Cornelius (Universiteit van Stellenbosch)
}

\section{Inleiding}

Die doel van hierdie artikel is om 'n oorsig te gee van die naleef of nawerking van $\mathrm{Ou}$ Egiptiese motiewe in die Suid-Afrikaanse argitektuur en boukuns. Watter rol het die inspirasie van Ou Egiptiese style en motiewe gespeel? Die Egyptian Revival (Curl 1994) is bekend in Europa, die Verenigde Koninkryk, Australië (Merrillees 1990 en 1995) en die VSA (Carrott 1978), maar wat is die geval in Suid-Afrika? So 'n oorsig is nog nie na behore onderneem nie. ${ }^{2}$

Soms word die term Egyptian Revival ("Egipte-herlewing") en die meer populêre Egyptomania (Afrikaans: Egiptomania) gebruik, ${ }^{3}$ maar Hornung (1994:1-2) meen die terminologie moet meer spesifiek wees. Hy gebruik Ägyptomanie vir onder andere films en advertensies, wat hy nie as deel van die kern van Ägypten-Rezeption ("Egipte-resepsie") beskou nie. In 'n latere ondersoek is hy selfs meer krities en reageer hy op wat hy 'n "verwarring van terminologie" noem (Hornung 1997:333). Hornung maak 'n duidelike onderskeid tussen die gebruik van Egiptiese motiewe in kuns en argitektuur asook in literatuur, musiek en godsdiens, enersyds, en die meer gewilde Egiptomania andersyds. Laasgenoemde term maak deel uit van wat hy die "periferie" noem soos dit tot uiting gekom het in die entoesiasme vir enigiets Egipties ná die ontdekking van die graf van TutankhAmen in 1922. Hy voeg hierby 'n derde term naamlik Ägyptosophie, die tradisie van esoteriese wysheid soos verteenwoordig deur Hermes Trismegistos en die latere ontwikkelings wat daarmee saamgaan (sien nou Hornung 2001). In 'n bydrae tot 'n bekende katalogus van 'n groot uitstalling in Parys en Ottawa (1994:21) waarsku Humbert ook teen die onoordeelkundige gebruik van die term Egiptomania. Daarteenoor gebruik Bob Brier (1993:41) die term Egiptomania om te verwys na enigiets wat die universele fassinering met Egipte weerspieël en wat teruggaan na antieke tye (vgl. Roullett 1972 t.o.v. antieke Rome).

1 Met dank aan die volgende persone: Pierre-Jacques Venter, René Fourie, Jo-Marie Claassen, Mimmie Seyffert (J.S. Gericke-biblioteek Stellenbosch Universiteit), en Anlen Boshoff (SA Kultuurhistoriese Museum Kaapstad). Ek wil die huidige hoof van die Laerskool Gimnasium, mnr. M.V. Carstens en mev. Ria Basson van die skool bedank vir hulle welwillendheid, sowel as mnr. I. Arendse (Drakenstein Heemkring) en mev. E. Powess (Paarl Museum). Marlene Goosen, wat 'n lesing van my oor Egyptomania bygewoon het by 'n byeenkoms van The Egyptian Society of $S A$, was die eerste om my in te lig oor die gebou in Kakamas. Ek wil vir Debbie Aggenbag en haar eggenoot hartlik bedank vir hulle gasvryheid gedurende ons verblyf in Kakamas. Margaret Harradine van die Hoofbiblioteek in Port Elizabeth het inligting verskaf oor die piramide in dié stad. Die finansiële ondersteuning van die NNS en die Universiteit van Stellenbosch word ook erken. Alle foto's is deur die skrywer self (C) I. Cornelius).

$2 \quad$ Sien Oberholster 1972:16; Greig 1971:174 en Claassen 1987:112, 118.

$3 \quad$ Vgl. Assmann 1997:17-19; Curl 1994; Brier 1993; Humbert et al. 1994; Hornung 1994; Iversen 1993; Morenz 1968; Pevsner \& Lang 1968; Staehelin \& Jaeger 1997; Whitehouse 1995. 
Die inskrywing in die Oxford Encyclopedia of Ancient Egypt (Fazzini en McKercher 2001:458) verstaan dit as die fassinering en invloed van Ou Egipte.

Die term Egyptian Revival word hier gebruik om nie net na een beweging te verwys nie, maar na verskeie tendense uit verskillende tydperke (vgl. Whitehouse 1995:17). 'n Onderskeid behoort gemaak te word en die term Egiptomania moet liefs uitgesonder word vir verskynsels wat grens aan 'n "obsessie" met enigiets Egipties. Daarnaas kom die term Egyptophilia ook voor - 'n liefde vir die antieke kultuur van Egipte. Die term Egyptianising word deur Curl gebruik om te verwys na die gebruik van antieke Egiptiese style in die Westerse kuns en argitektuur (1994:xvi). Dit sluit voorbeelde in waar antieke Egipte as bron van inspirasie gedien het. In dié artikel sal daar nie verder op meer spesifieke kunsterme soos Neo-Egipties, Neo-Klassisisme en Art Déco ingegaan word nie.

Elke Suid-Afrikaanse gebou wat vervolgens bespreek word, word ondersoek ten opsigte van:

- die geskiedenis,

- die voorkoms van Egiptiese of kwasi-Egiptiese elemente daarin (naamlik 'n vergelyking met die Antieke),

- asook moontlike redes vir die gebruik van sodanige motiewe (genoem "Egiptiserend" vir die Engelse Egyptianising) en

- die huidige toestand daarvan.

2. Bespreking van die materiaal

2.1 Laerskool Gimnasium in die Paarl [Fig. 1A].

Aangesien dié gebou so mildelik met Egiptiserende motiewe versier is, kom die Laerskool Gimnasium in die Paarl $(50 \mathrm{~km}$. noord van Kaapstad) eerste onder bespreking. ${ }^{4}$ Dit is geleë in Hoofstraat net oorkant die sogenaamde "Toringkerk", is in 1858 opgerig, en is in 1968 tot nasionale monument verklaar. Tans word dit steeds as 'n laerskool vir seuns en dogters gebruik. Die skool was oorspronklik 'n kerkskool waar seuns opleiding kon ontvang voordat hulle na die Teologiese Kweekskool gegaan het of in Europa gaan studeer het. Een van die onderwysers was verantwoordelik vir die onderrig van "Klassieke Tale, Antieke Geskiedenis en Mitologie" (Oberholster 1972:90).

Die gebou, wat dateer uit 1868-1869, vertoon duidelik antieke Egiptiese invloede. Die hoofingang is in die vorm van 'n reusagtige Egiptiese tempelpoort (piloon/pylon), met die tipiese spits sye en die cavetto corniche ('n konkawe lyswerk aan die bokant van Egiptiese stelae, geboue en altare) $[$ Fig. $1 B] .^{5}$ Die cavetto-patroon word ook op die symure aangetref. Die vensters het hierdie patroon aan hul bokant en

$4 \quad$ Vgl. Fransen \& Cook 1980:201-2; Greig 1971:174; Oberholster 1972:90-91 en Picton-Seymour 1977:141.

5 Vir 'n beskrywing en illustrasie van die belangrikste Ou Egiptiese bouterme, sien die werk van Arnold 1994. 
is versier met 'n gevleuelde son. Dit sou vergelyk kon word met 'n gebou uit die Egiptiese Revival (vgl. Curl 1994:236), naamlik Bullock se "Egyptian Halls" wat dateer uit 1812 (Curl 1994:156-157, Fig. 110; MacKenzie 1995:78, 81, Fig. 71) met sy poorte, cavetto's en gevleuelde sonskywe. In die geval van die Paarl Gimnasium lyk dit nie asof die motiewe by enige spesifieke model van 'n bekende Egiptiese tempel oorgeneem is nie.

Wanneer daar vanaf die uiterlike argitektoniese vorm oorgegaan word na die versierings, sien mens dat die gebou met Egiptiese motiewe in stucco (pleisterkalk) versier is. Op die sentrale kloktoring kom daar baie Egiptiese versierings voor: blompatrone en 'n pragtige gevleuelde sonskyf met uraei (Egiptiese kobras). Rondom die plek waar die horlosie was, is daar 'n ry skarabeë (heilige kewers) met blompatrone daarnaas. Hieronder is 'n fries van Egiptiese uraei met sonskywe op hulle koppe, asook gevleuelde sonskywe en sterre [Fig. 1C]. Wat veral opmerklik is, is die gevleuelde sonskywe wat op meer as een plek voorkom. Direk bokant die hoofingang van hout met sy gewelvenster is 'n groot sonskyf met vleuels en vier kruipende skarabeë [Fig. 1B].

Op die gewels van die twee vleuels kom daar verskeie versierings voor [Fig. $1 D]$. Die kop van die godin Hathor en die bekende Egiptiese sfinks is opvallend. Die kop van Hathor word vertoon met 'n naos en 'n sonskyf met horings daarbinne. Verder is daar versierings soos die aasvoël-godin Nekhbet, nog 'n gevleuelde son met strale, en ander patrone. Aangesien hierdie slegs 'n oorsig is, word daar nie besondere aandag aan elke faset gegee nie en word sommige versierings gelaat vir 'n toekomstige detailstudie van die motiewe by hierdie skool.

Waar kom hierdie Egiptiese motiewe vandaan? Die oorsprong daarvan kan nagespeur word tot by die stigter van die skool, ds. G.W.A. van der Lingen, wat 'n direkte invloed op die versierings gehad het en selfs sy eie geld daaraan bestee het. Hierdie eksentrieke persoonlikheid het verskeie Oosterse tale bestudeer (De Villiers 1874:240), was welbelese en het 'n persoonlike boekery van 10000 volumes besit (Kitshoff 1972:263), soos blyk uit 'n lys uit 1870 (Catalogus van een belangrijke verzameling goed gekonditioneerde boeken ...). Dit is opgestel deur die beroemde Arnoldus Pannevis, 'n onderwyser by die skool en later 'n baanbreker in die stryd vir die erkenning van Afrikaans as taal. Die lys sluit baie volumes oor Egipte en die Ooste in, soos Vivant Denon se Description de l'Égypte (vgl. Kitshoff 1972:267). Van der Lingen het ook kopieë van die Voyage van Denon, die Pyramids van Vyse, en Birch en Salt se boeke oor Egiptiese hiërogliewe besit. Dit is bekend dat hy die spekulasies van Piazzi Smyth oor die Groot Piramide bestudeer het, maar hy is nie daardeur oortuig nie (De Villiers 1874:242). Een biograaf merk op dat hy veertig boeke bestudeer het om 'n suiwer Egiptiese boustyl daar te stel (De Kock 1983:136). Hy was 'n bewonderaar van die antieke Egiptiese kultuur en het na bewering Egiptiese hiërogliewe bestudeer (Fransen \& Cook 1980:210; Lantern 37/2, 6 Mei 1988, 63), maar in watter mate kon nog nie vasgestel word nie.

Merrington (2001:332; vgl. ook sy artikel van 1995, veral 649 ff.) behandel die "Kaap na Kaïro"-motief en verwys ook na die Paarl Gimnasium. Hy wys 'n moontlike verband uit tussen die Egiptiserende motiewe en die Nederlandse tradisie 
van Vrymesselary aan die Kaap. Laasgenoemde is egter onwaarskynlik, want ds. van der Lingen was baie negatief oor die Vrymesselaars van die Kaap (Cooper 1986:150).

Die leuse van die skool, Sol iustitiae illustra nos ("die son van geregtigheid skyn oor ons") is geneem uit Maleagi 3:20 in die Hebreeuse Bybel (in die vertalings 4:2) en is ook die leuse van die Universiteit van Utrecht in Nederland, waar ds. Van der Lingen studeer het. Dié leuse versterk ook die simboliek van die son en die verband met Egipte. Die leuse is tans nie sigbaar teen die mure van die skool nie, maar was na bewering onder die venster in die toring (Kitshoff 1972:137). Dit verskyn ook op die voorste gewel van die Nederduits-Gereformeerde kerk in dieselfde dorp (die sogenaamde Paarlse Strooidakkerk van 1805), waar Van der Lingen gepreek het, en dit word ook later (1863) as leuse van die Stellenbosse Teologiese Kweekskool gebruik.

Geen voorbeelde wat vergelyk met die argitektuur en versiering van hierdie skool kon gevind word nie, selfs nie uit die tydperk na die ontdekking van TutankhAmen se graf nie, en ook nie by hedendaagse geboue in Suid-Afrika nie. Die Paarl Gimnasium is 'n unieke voorbeeld en 'n hoogtepunt van Egiptiserende motiewe in die Suid-Afrikaanse argitektuur.

Selfs die grafsteen van Van der Lingen in die Paarl toon Egiptiese motiewe [Fig. 1E]. In die kerkhof van die Moederkerk op Stellenbosch is daar 'n vergelykbare grafsteen van die bekende dominee Herold. Dit is in die vorm van 'n Egiptiese piloon met 'n cavetto corniche-patroon [Fig. $1 F]$.

\subsection{Die Egiptiese gebou van die Universiteit van Kaapstad [Fig. 2A-B]}

Die oudste gebou in die Kaap wat die styl van die Egipte herlewing weerspieël, is geleë in Kaapstad, in die Tuine langs die Parlement.

Naby Bertramhuis aan die regterkant van die Laan staan die "Egiptiese gebou" van die Universiteit van Kaapstad (Fransen \& Cook 1980:47; Greig 1971:94; Oberholster 1972:16). Dit is die oudste bestaande gebou van die eerste "Europese" Universiteit in Suid-Afrika en dateer uit 1841. Dit is dus ouer as die Paarlse Gimnasium en het moontlik as voorbeeld vir Van der Lingen gedien, hoewel die gebou in die Paarl oordadiger versier is.

Die "Suid-Afrikaanse Kollege" is in 1829 gestig en in 1838 het die goewerneur, Sir Benjamin D'Urban, eiendom aan die Kollege toegestaan. James Adamson, professor in Engels en Natuurstudie, het dit ontwerp en kol. G G Lewis van die Royal Engineers het die ontwerp hersien. Dit is in 1841 geopen en in 1969 tot nasionale monument verklaar.

Die gebou het Egiptiserende onversierde pilare met klokvormige kapitele wat lyk soos papirus. Die syvleuels is versier met piloonagtige versierings in pleisterreliëf. Die dak vertoon ook 'n cavetto corniche-patroon en aan die kant wat aan die Laan grens, is nog pylonversierings met sonskywe. Verder is daar aangepaste gevleuelde sonskywe bokant die vensters [Fig. 2B].

Tot dusver kon geen spesifieke redes vir die gebruik van die Egiptiese boustyl gevind word nie. Dit sou toegeskryf kon word aan die voortdurende uitwerking van die nuwe belangstelling in Egipte ná die ekspedisie van Napoleon (1798) en die 
publikasies van Denon (die finale volume is in 1828 gepubliseer), hoewel Merrington meen dat dit teruggevoer kan word na die Vrymesselary-beweging aan die Kaap (1995:650). Dalk was daar meer as een rede vir die keuse van sodanige styl. Een hiervan mag wees dat Egipte tradisioneel bekend was as 'n plek van onderrig en wysheid en dat die styl daarom gepas sou wees vir 'n onderriginstelling. Dieselfde rede sou kon geld vir die Paarlse Gimnasium, hoewel die persoonlike invloed van Van der Lingen daar ongetwyfeld 'n groot rol gespeel het.

\subsection{Die Ou Sinagoge in die Tuine, Kaapstad [Fig. 3]}

Die oudste Joodse gemeenskap in Suid-Afrika dateer uit 1841 en die eerste sinagoge is in 1849 gebou. Dit is genoem Tikvath Israel ("hoop van Israel"), 'n sinspeling op (Kaap van) "goeie hoop". Die huidige sinagoge is op 13 September 1863 ingewy. 6

Bokant die ingang is ' $n$ fasade in die vorm van 'n piloon met 'n groot cavetto corniche met 'n vertikale, lineêre patroon. Die pilare aan die voorkant is ook Egipties, maar kan nie juis vergelyk word met enige bekende Egiptiese voorbeelde nie. 'n Mens sou verwag dat die kapitele lotus- of papirusvormig sou wees (vgl. Curl 1994:4:Pl. 1o-t), maar nadere ondersoek het getoon dat dit lyk soos 'n papirusvormige kapiteel met iets soos wingerdblare. Aan die onderkant van die basis is daar palmagtige versierings. Greig (1971:96) beskryf dit as "a mixture of decorative acanthus and palm leaves and lotus flowers".

Sinagoges in hierdie styl word ook elders aangetref, veral in die VSA (Curl 1994:189 en Wischnitzer 1975:347), maar daar kon tot dusver geen ander spesifieke redes vasgestel word vir die keuse van die Egiptiserende styl nie.

\subsection{Die Vuurtoring van L'Agulhas [Fig. 4A]}

Die Vuurtoring van L'Agulhas op die mees suidelike punt van Afrika word genoem die "Faros van die Suide". Dit is vanaf 1849 in gebruik en is die tweede oudste vuurtoring in SA. Die oorspronklike planne van 1848 is in die Transnet-Argief (Van Bart 1993). Die ou kalksteentoring is in 1962 vervang en na restourasie weer in 1988 in gebruik geneem.

Van naderby beskou, vertoon die kalksteengebou aan die see se kant 'n piloonvormige ingang [Fig. 4B]. Bokant die sentrale ingang is 'n versiering van 'n gevleuelde sonskyf met uraei. 'n Deel van die versiering het afgebreek en word binne-in die museum bewaar. Die dak en die vensters vertoon ook die bekende cavetto-patroon.

Waarom is 'n vuurtoring in só 'n styl in die verre suide gebou? Die Britse goewerneur, Sir Harry Smith, wat aan bewind was ten tye van die oprigting, het versoek dat die gebou kultuur en beskawing moes weerspieël by hierdie ongerepte buitepos (Van Bart 1993). Dit blyk baie gepas te gewees het om 'n vuurtoring met Egiptiserende motiewe in die tradisie van een van die (verlore) wonders van die

6 Contra Claassen 1987:112 wat 1882 aandui; vgl. Greig 1971:96 en Fransen \& Cook 1980:49. 
antieke wêreld te bou. Hoe die argitek egter die toring van Faros voorgestel het, kon nog nie vasgestel word nie.

\subsection{Die Donkin-Piramide in Port Elizabeth [Fig. 5]}

Die oudste gebou in Suid-Afrika met Egiptiese invloed wat tot dusver opgespoor kon word, dateer uit Augustus 1820 en is in 1938 tot nasionale monument verklaar. Dit is die piramide met sy skuins hellings op Donkinheuwel in ou Portugese Algoabaai (tans die Oos-Kaapse hawe van Port Elizabeth aan die Indiese Oseaan), waar die eerste Britse Setlaars op Suid-Afrikaanse grond voet aan wal gesit het. Dit is 'n klippiramide en is gebou deur Sir Rufane Donkin, wat goewerneur was in die plek van Lord Charles Somerset, toe dié van 1820-1821 in Engeland was. Hy het dit opgerig ter herinnering aan sy vrou Elizabeth (dogter van dr. George Markham, Deken van York), wat in 1818 in Indië oorlede is en na wie die stad vernoem is. Die inskripsie lui: "To the memory of one of the most perfect of human beings, who has given her name to the town below" (Oberholster 1972:133-134).

Piramides is sinoniem met Egipte, maar daar is 'n hele paar "Revival"voorbeelde (vgl. Lehner 1998:240-243). Volgens Margaret Harradine (1991) het hierdie piramidevorm egter nie sy oorsprong in Egipte nie, maar in Brittanje by piramides van die 1700's, toe dit baie gewild was (soos die voorbeeld by Castle Howard, Yorkshire - vgl. Curl 1994:84). Die model hiervoor was die piramide-graf met baie skuins hellings van die tribuun Caius Cestius by die Porta San Páolo in Rome (12 v.C.), geleë naby die grafte van die digters Shelley en Keats (Curl 1994:2526, Fig. 15; Humbert 1994:114). In latere tye in antieke Egipte is piramides ook opgerig om grafte aan te dui, soos by Deir el-Medina in die Vallei van die Konings. Een voorbeeld (vgl. in Lehner 1998:193) het ook 'n skuinser helling en dit sou kon aandui dat Curl (1994:25) se argument, dat die piramide van Caius teruggaan na die piramides van Kusj en Meroe (in die Soedan) met hulle skuinser hellings, nie heeltemal geregverdig is nie. ' $n$ Latere voorbeeld is die senotaaf van die aartshertogin Maria Christina van Oostenryk, wat ontwerp is deur Antonio Canova en in 1805 gebou is (vgl. Curl 1994:Fig. 126; Lehner 1998:243).

Geen ander voorbeelde van piramides met hierdie vorm kon in Suid-Afrika opgespoor word nie, hoewel die vorm in geboue en selfs in privaat wonings gebruik word, soms om die gedagte van "pyramid power" (die siening dat die piramiedevorm oor sekere helende en kosmo-magiese kragte beskik) weer te gee.

\subsection{Transformatorgebou in Kakamas [Fig. 6]}

In die klein dorpie Kakamas in die Noord-Kaap staan die sogenaamde Transformatorgebou in Voortrekkerstraat, die hoofstraat. Dit was een van die eerste plekke in Suid-Afrika met elektrisiteit. Die gebou is nie baie indrukwekkend nie, hoewel dit mens herinner aan die piloonagtige vorm van 'n Egiptiese tempel met sy corniche, maar nie met die tipiese cavetto of helling nie. Die naam van die gebou is geskryf in Fenisiese letters, wat nog 'n skakel met die Antieke verskaf. Dit is in 1914 deur die Switserse argitek Hangartner langs die ou koringmeul opgerig. Die gebou is 
sedert 1998 'n museum (vgl. Hopkins 1978:130 -131 en Bylaag tot GemsbokKakamas Junie 2000:39, 41).

Daar word gesê dat Hangartner vir 'n Egiptiserende styl gekies het omdat hy geredeneer het dat Kakamas op dieselfde lengtegraad as dele van Egipte ( $\left.28^{\circ} 44^{\prime}\right)$ geleë is en beide plekke geweldig warm is. Hierby kan nog gevoeg word dat 'n rivier in beide gebiede so prominent is. Kakamas is inderdaad 'n "geskenk" van die Oranjerivier - soos die Mississippi die "Nyl van Amerika" is (Wischnitzer 1975:349). Wanneer mens deur hierdie gebied reis, kom jy gou onder die indruk van die belangrike rol wat die rivier speel om 'n paradys in 'n baie droë gebied te skep, baie soos die Nyl in Egipte.

\subsection{Obeliske in Bloemfontein en Kakamas [Fig. 7A-B]}

Vandag is daar meer oorspronklike obeliske buite as in Egipte self (Habachi 1978 en Iversen 1968 \& 1972). Daar bestaan ook 'n groot aantal nie-Egiptiese monumente in hierdie styl, waarvan die Washington Memorial die grootste obelisk is wat bestaan. ${ }^{7}$ Die styl word ook algemeen gebruik vir grafstene, soos aangetoon deur Joachim Sliwa (1999:14-16) in sy artikel oor Egiptiserende monumente in die Bromptonbegraafplaas in London.

In Suid-Afrika is daar die obelisk by die Vrouemonument in Bloemfontein (Van Schoor 1993) [Fig. 7A]. Die sandsteenobelisk van 36,5 meter met 'n brons punt is ontwerp deur die beeldhouer Anton van Wouw en op 16 Desember 1913 onthul. Die monument gedenk die meer as 20000 vrouens en kinders wat in die Engelse Oorlog (ook genoem die Anglo-Boere-oorlog) van 1899-1902 gesterf het. Geen redes vir die spesifieke keuse van 'n obelisk deur die beplanners en beeldhouer kon tot dusver gevind word nie.

'n Ander klein obelisk is een wat in 1998 in Kakamas opgerig is om die gedwonge verskuiwing en skending van grafte onder die apartheidsregering te gedenk [Fig. 7B]. Die inskripsie in Afrikaans lui:

Ter gedagtenis van 150 Bruin en Swart geliefdes wat ons vooruitgegaan het en hier te ruste gelê is. Wie se grafte gedurende die Apartheidsjare in 1986 met gedwonge verskuiwing gesloop was. Ons eer hul nagedagtenis.

Daar is dus een voorbeeld uit die tydperk voor die ontdekking van die graf van TutankhAmen en een uit die tyd daarna. In beide gevalle is 'n obelisk gekies om die nagedagtenis van gestorwenes te gedenk, maar om verskillende ideologiese beweegredes. In teenstelling met die obelisk in Bloemfontein ter nagedagtenis van Boere-vrouens en -kinders wat in die Engelse oorlog omgekom het, is daar 'n Australiese voorbeeld ter nagedagtenis van Australiese soldate wat in dieselfde oorlog gesneuwel het terwyl hulle aan die Britse kant geveg het (Merillees 1990:59). Geen

Die Washington Memorial is $169 \mathrm{~m}$. teenoor die "onvoltooide obelisk" van $41.75 \mathrm{~m}$. wat in die steengroewe van Aswan lê. Die hoogste staande obeliske is die een in Laterano, Rome (32.18 m.) en een van die vroulike farao Hatshepsut in Karnak (29.56 m.). 
prominente hedendaagse voorbeelde (ander voorbeelde uit gewone begraafplase buite rekening gelaat $)^{8}$ wat hiermee vergelykbaar is, kon tot dusver gevind word nie.

\subsection{Die Colosseumteater in Johannesburg}

Ná die ontdekking van die graf van TutankhAmen in 1922, het die Art Déco styl met sy Egiptiese kenmerke in Europa en Amerika posgevat (Curl 1994:211-220, 230; Humbert 1994:508 ff.). Gedurende hierdie tydperk is nie alleen baie mummie- en Cleopatra-films vervaardig nie, maar is die neiging ook weerspieël in die argitektuur van die bioskope en teaters wat toe gebou is. 'n Suid-Afrikaanse voorbeeld hiervan is die Colosseumteater in Johannesburg, wat in die 1930's gebou is, maar ongelukkig in die 1970's gesloop is. Vanaf ou foto's kry mens 'n idee hoe dit gelyk het. Martin (1987:23-24) beskryf dit as 'n gebou met 'n fasade, ses Egiptiserende pilare, brons papiruskapitele en losstaande vroulike beelde in nisse. Die oorspronklike ontwerpers het gemeen hulle bou in die "ou Romeinse styl"; vandaar die Latynse naam.

Hierdie is die enigste duidelike Egiptiserende voorbeeld uit die post-1922 tydperk wat tot dusver opgespoor kon word. In teenstelling met die ander voorbeelde uit die 19de eeu (wat plekke van onderrig en aanbidding, gedenkmonumente en 'n transformator insluit), is Egiptiserende motiewe in hierdie geval gebruik in 'n plek van vermaak. 'n Ander hedendaagse voorbeeld (dog een waarby die term "Egyptokitsch" dalk eerder sou pas) is die restourant "Cleopatra's Table" by die casino "Caesar's Palace" in Gauteng naby Johannesburg. ${ }^{9}$ Dit is versier met groot standbeelde wat herinner aan die beelde van Antinoüs (geliefde van keiser Hadrianus wat in die Nyl verdrink het, sulke beelde was baie gewild in Rome [Curl 1994:Pl. 19]). Die gaste sit aan op 'n Egiptiserende boot, wat dalk 'n nabootsing is van die boot waarop Cleopatra vir Marcus Antonius ontmoet het en wat so raak deur Plutargos beskryf is.

\section{Gevolgtrekkings}

In hierdie oorsig is geboue bespreek wat Egipte as 'n bron van inspirasie vir 'n verskeidenheid terreine weerspieël:

- plekke van onderrig, aanbidding en vermaak: die Laerskool Gimnasium in die Paarl (2.1) en die gebou van die Universiteit van Kaapstad (2.2); die Ou Sinagoge in Kaapstad (2.3); en die Colosseumteater in Johannesburg (2.8)

- om te gedenk: die Donkinpiramide (2.5) en die twee obeliske (2.7)

- om die voordele van tegnologie uit te wys: die vuurtoring van L'Agulhas (2.4) en die Transformatorgebou in Kakamas (2.6).

\footnotetext{
8 Dit is opmerklik hoe baie obeliske nog steeds in gewone begraafplase voorkom.

9 Vgl. die webtuiste by www.caesars.co.za/entertainment/default.htm.
} 
Die beweegrede vir 'n belangstelling in Egipte kan nie beperk word tot slegs een ontdekking of tydperk nie, hoewel die invloed van die uitwerking van Napoleon se ekspedisie en Denon se publikasie op die Laerskool Gimnasium duideliker te sien is, as wat die ontdekking van TutankhAmen se graf 'n invloed blyk te gehad het op die Art Déco-styl van die Colosseumteater in Johannesburg. Die inspirasie vir die Donkinpiramide was afkomstig, soos aangedui is, van Brittanje en nié van Egipte self nie. Vrymesselary sou 'n invloed kon gehad het, maar dit moet eers met groter sekerheid bevestig word (contra Merrington 1995 en 2001).

Alhoewel die voorbeelde uit Suid-Afrika beperk is en skaars vergelyk kan word met wat mens in Europa, die Verenigde Koninkryk en die VSA aantref, het die Egyptian Revival nietemin tot uitdrukking gekom in 'n plek so ver verwyderd van Europa as die Kaap die Goeie Hoop aan die mees suidelike punt van die Afrika kontinent (ironies genoeg op dieselfde kontinent as die antieke Egiptiese beskawing, maar met die inspirasie afkomstig via Europa). Lewcock (1963:339) meen selfs dat die Egiptiese Revival nooit so 'n groot impak op die Engelse argitektuur gehad het as op die Kaap nie. Soos aangedui, was dit nie alleen as gevolg van die Britse kultuur en die invloed daarvan (die Kaapstadse Universiteitsgebou en die Donkinpiramide) nie, maar het dit ook neerslag gevind in die pogings van plaaslike persoonlikhede soos ds. Van der Lingen, wat Egiptiese motiewe gebruik het om die Afrikaanse taal en kultuur te bevorder. In die meeste van die bouwerke onder bespreking kan die styl as "elitisties" beskryf word, hoewel die twee obeliske (wat twee verskillende ideologieë weerspieël) en die teater 'n meer algemene publiek in gedagte gehad het.

Hierdie artikel was 'n bestekopname en wou 'n oorsig gee van die beskikbare bronne en niks meer nie. Daar is gepoog om die redes na te gaan waarom argitekte en beplanners sulke style gekies het. In die meeste gevalle was die antwoorde tot op datum onvolledig en onbevredigend.

\section{BIBLIOGRAFIE}

Arnold, D 1994. Lexikon der ägyptischen Baukunst. München: Artemis.

Assmann, J 1997. Moses the Egyptian. The memory of Egypt in western monotheism. Cambridge, Mass.: Harvard University Press.

Brier, B 1993. Egyptomania. Surveying the age-old fascination with ancient Egypt. KMT 4(1):40-51.

Carrott, R G 1978. The Egyptian revival. Its sources, monuments, and meaning. Berkeley: University of California.

Claassen, J-M 1987. Functional and symbolic use of domes and arches in some examples of South African religious architecture. The South African Journal of Culture, Art and History 1(2):110-120.

Cooper, A A 1986. The Freemasons of South Africa. Cape Town: Human \& Rousseau.

Curl, J S (ed.) 1994. Egyptomania. The Egyptian revival. A recurring theme in the history of taste. Manchester: Manchester University Press. 
De Kock, A J 1983. Die Gimnasium in die Paarl, 1858-1908: 'n historiese studie (unpublished DPhil dissertation, University of Stellenbosch).

De Villiers, J M W van der Lingen 1874. Herinnering aan het leven en den arbeid van den weleerw. zeer geleerden heer Gottl. Wilh. Anth. van der Lingen, in leven herder en leeraar der Nederd. Gereformeerde Gemeente aan de Paarl. Kaapstad: Smuts \& Hofmeijr.

Fazzini, R A \& McKercher, M E 2001. Egyptomania. In Redford, D B (ed.), The Oxford Encyclopedia of Ancient Egypt, Vol. I, 458-465. Oxford: Oxford University Press.

Fransen, H \& Cook, M A 1980. The old buildings of the Cape: a survey and description of old buildings in the Western Province extending from Cape Town to Calvinia in the north and to Graaff-Reinet, Colesberg and Uitenhage in the east. Cape Town : Balkema.

Habachi, L 1978. The obelisks, skyscapers of the past. London: Dent.

Greig, D 1971. A guide to architecture in South Africa. Cape Town: Howard Timmins.

Harradine, M 1991. More about our pyramid. Looking back. Journal of the Historical Society of Port Elizabeth March 1991:24.

Hopkins, H C 1978. Kakamas - uit die wildernis 'n lushof. Kaapstad: Nasionale Boekdrukkery.

Hornung, E (ed.) 1994. Zum Bild Ägyptens im Mittelalter und in der Renaissance (OBO 95). Freiburg Schweiz: Universitätsverlag \& Göttingen: Vandenhoeck \& Ruprecht.

Hornung, E 1997. Hermetische Weisheit: Umrisse eine Ägyptosophie. In Staehelin \& Jaeger 1997:333-342.

Hornung, E 2001. The secret lore of Egypt. Its impact on the West. London \& Ithaca: Cornell University.

Humbert, J-M 1994. Egyptomania: a current concept from the Renaissance to Postmodernism. In Humbert 1994:21-26.

Humbert, J-M, Pantazzi, M \& Ziegler, C (eds) 1994. Egyptomania. Egypt in Western art, 1730-1930. Ottawa: National Gallery of Canada.

Iversen, E 1993 (reprint of 1961). The myth of Egypt and its hieroglyphs. In European tradition. Princeton: Princeton University Press.

Iversen, E 1968 and 1972. Obelisks in exile I-II. Copenhagen: Gad Publishers.

Kitshoff, M C 1972. Gottlieb Wilhelm Antony van der Lingen. Kaapse predikant uit die negentiende eeu (Proefschrift Vrije Universiteit Amsterdam).

Lehner, M 1998. The complete pyramids. London: Thames \& Hudson.

Lewcock, R 1963. Early nineteenth century architecture in South Africa. A study of the interaction of two cultures 1795-1837. Cape Town: Balkema..

MacKenzie, J 1995. Orientalism. History, theory and the arts. Manchester: Manchester University Press.

Martin, M 1987. An architecture for the masses. The movie palaces of the 1930s. Architecture SA May/June 1987:22-25. 
Merrillees, R (ed.) 1990. Living with Egypt's past in Australia. Melbourne: Museum of Victoria.

Merrillees, R 1995. Egyptomania in Australia. Bulletin of the Australian Centre for Egyptology 6:77-87.

Merrington, P 1995. Pageantry and primitivism: Dorothea Fairbridge and the 'Aestethics of Union'. Journal of South African Studies 21(4), 643-656.

Merrington, P 2001. A staggered Orientalism: the Cape-to-Cairo imaginary. Poetics Today 22(2):323-364.

Morenz, S 1968. Die Begegnung Europas mit Ägypten. Berlin: Akademie-Verlag.

Oberholster, J J 1972. The historical monuments of South Africa. Cape Town. Cape Town: Rembrandt van Rijn Foundation for Culture.

Pevsner, N \& Lang, S 1968. Studies in art, architecture and design, Vol. I. London: Thames and Hudson.

Picton-Seymour, D 1977. Victorian buildings in South Africa, including Edwardian \& Transvaal Republican styles, 1850-1910: a survey of houses, churches, schools, public and commercial buildings with notes on the materials used, the architects concerned, the use of prefabricated ironmongery and the influence of European styles. Cape Town: Balkema.

Roullett, A 1972. The Egyptian and Egyptianizing monuments of Imperial Rome. Leiden: Brill.

Sliwa, J 1999. Egyptianizing grave monuments in London's Brompton cemetery. In Studies in Ancient Art and Civilization 9:11-21.

Staehelin, E \& Jaeger, B (Hrsg.) 1997. Ägypten-Bilder. Akten des "Symposions zur Ägypten-Rezeption", Augst bei Basel, vom 9.-11. September 1993. Freiburg Schweiz: Universitätsverlag \& Göttingen: Vandenhoeck \& Ruprecht.

Van Bart, M 1993. Stabilisering van ou boumateriaal dalk groot deurbraak. Bylae Die Burger 20/3/1993.

Van Schoor, M C E 1993. Die Nasionale Vrouemonument. Bloemfontein: Oorlogsmuseum.

Whitehouse, R 1995. Egypt in European thought. In Sasson, J W (ed.), Civilizations of the ancient Near East, 15-31. New York: Scribner's.

Wischnitzer, R 1975. The Egyptian revival in synagogue architecture. In Gutman, J (ed.), The synagogue: studies in origins, archaeology and architecture, 334350. New York: Ktav. 


\section{ILLUSTRASIES}

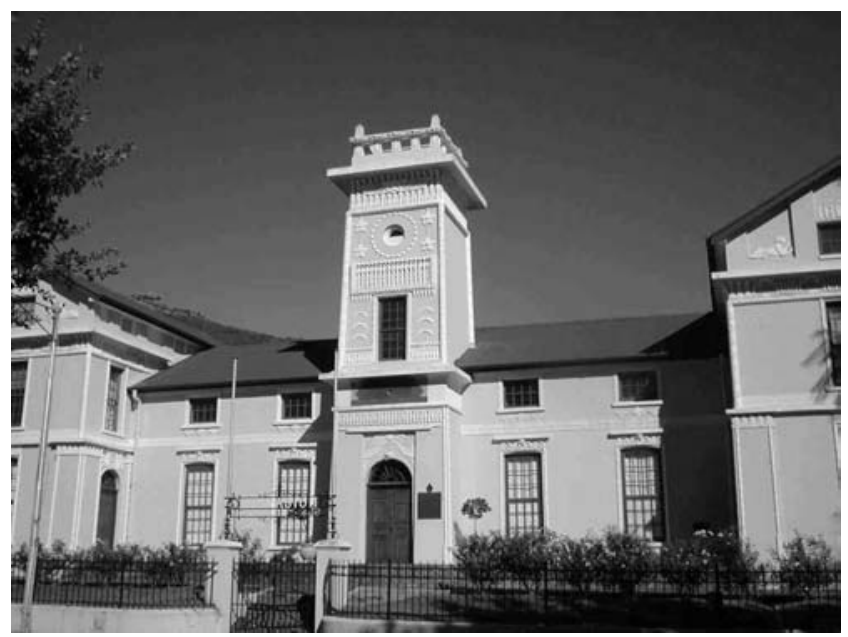

Fig. 1A: Paarl Gimnasium

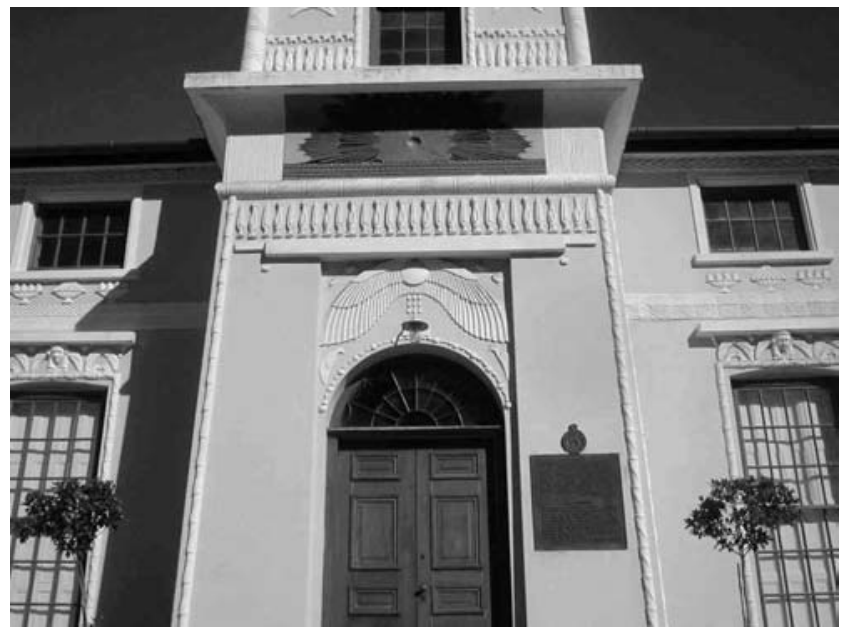

Fig. 1B: Paarl Gimnasium: hoofingang met geveuelde sonskyf

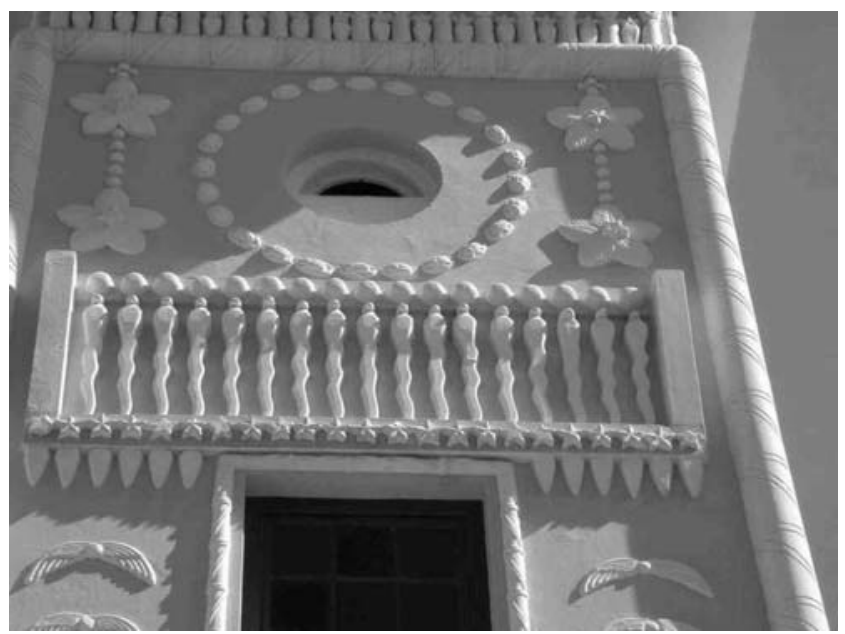

Fig. 1C: Paarl Gimnasium: kloktoring met skarabeë en uraei 


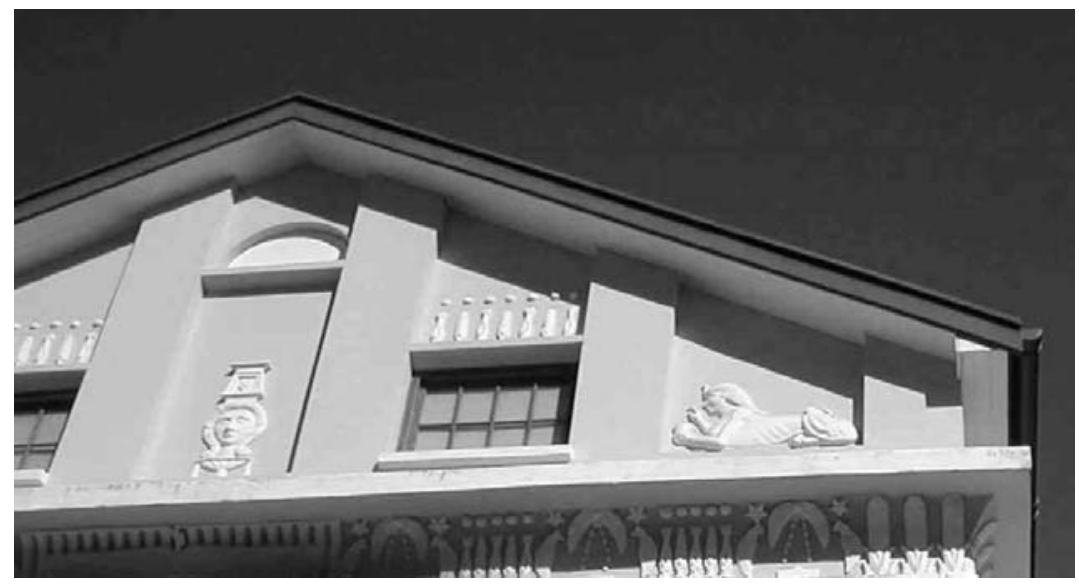

Fig. 1D: Paarl Gimnasium: Hathor en sfinks

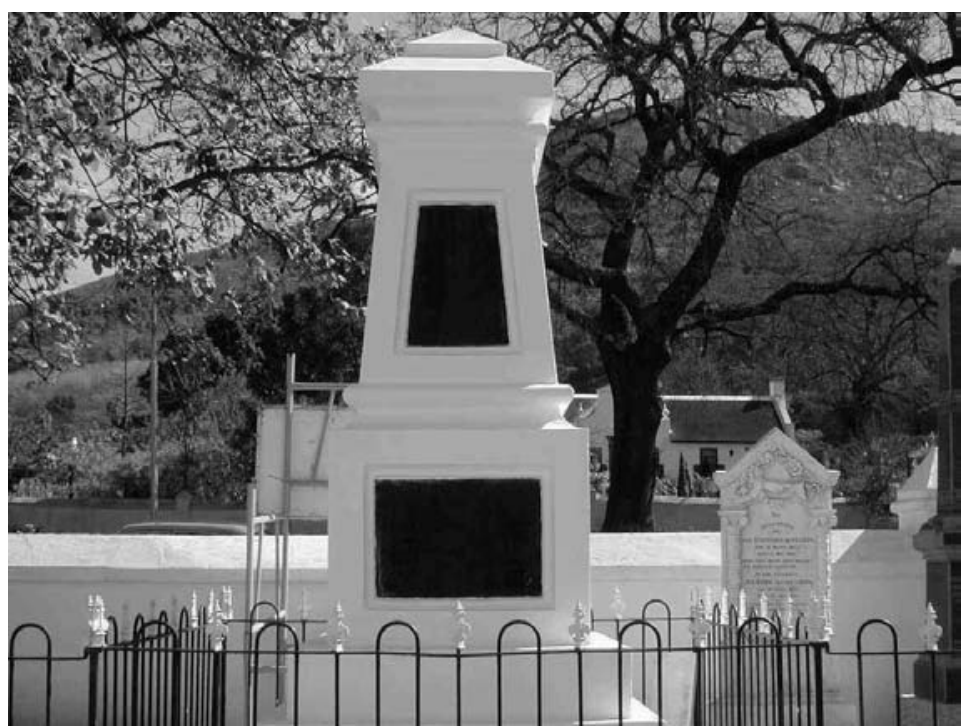

Fig. 1E: Paarl: graf van ds van der Lingen

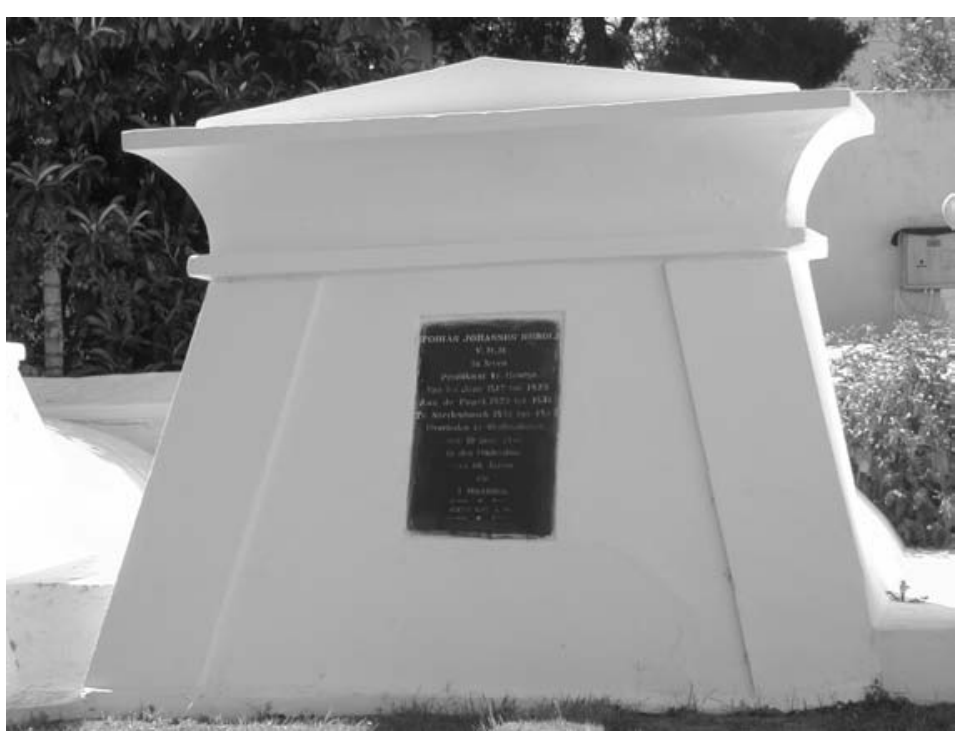

Fig. 1F: Stellenbosch: graf van ds Herold 


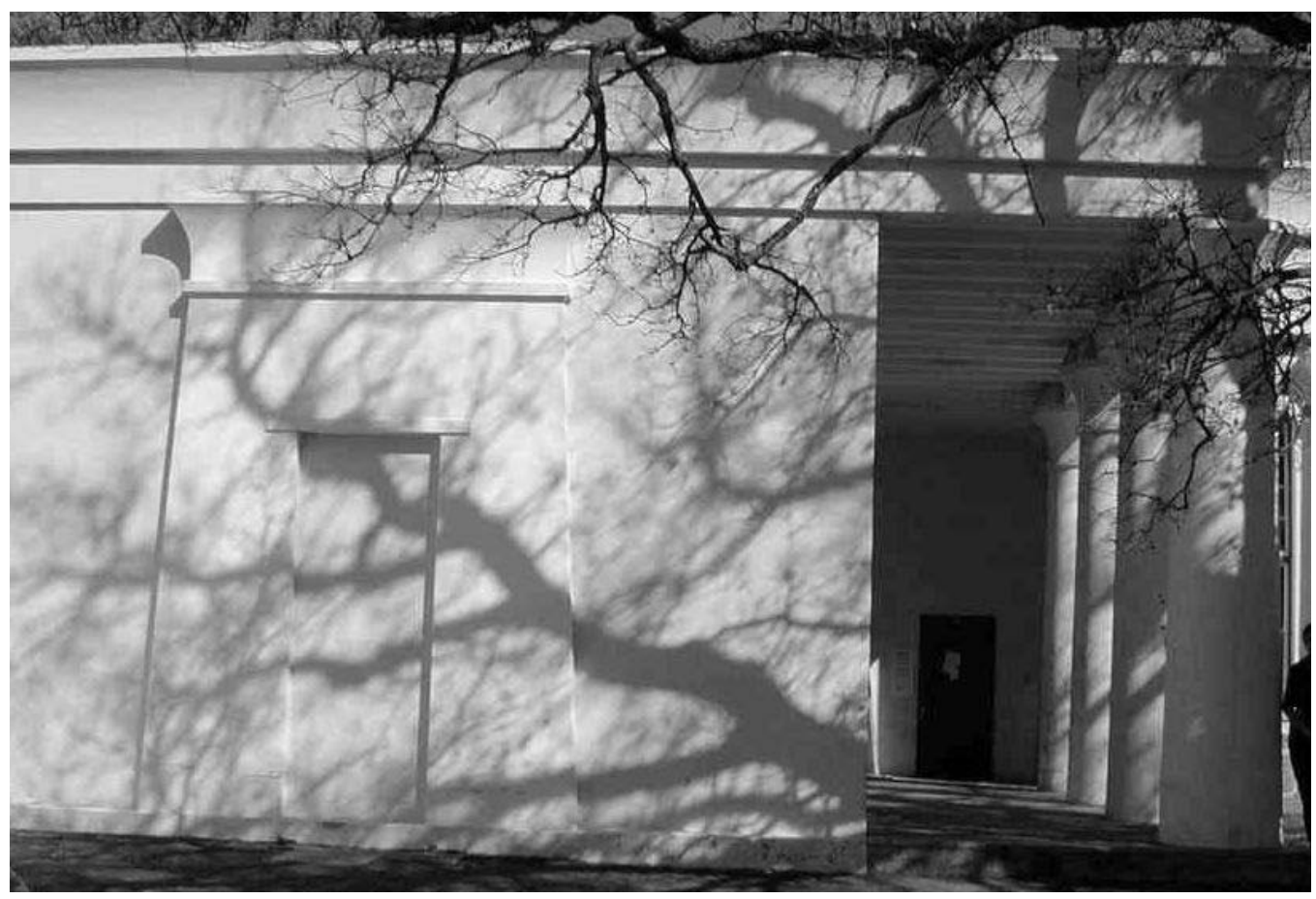

Fig. 2A: Egiptiese gebou, Universiteit van Kaapstad: piloon en pilare

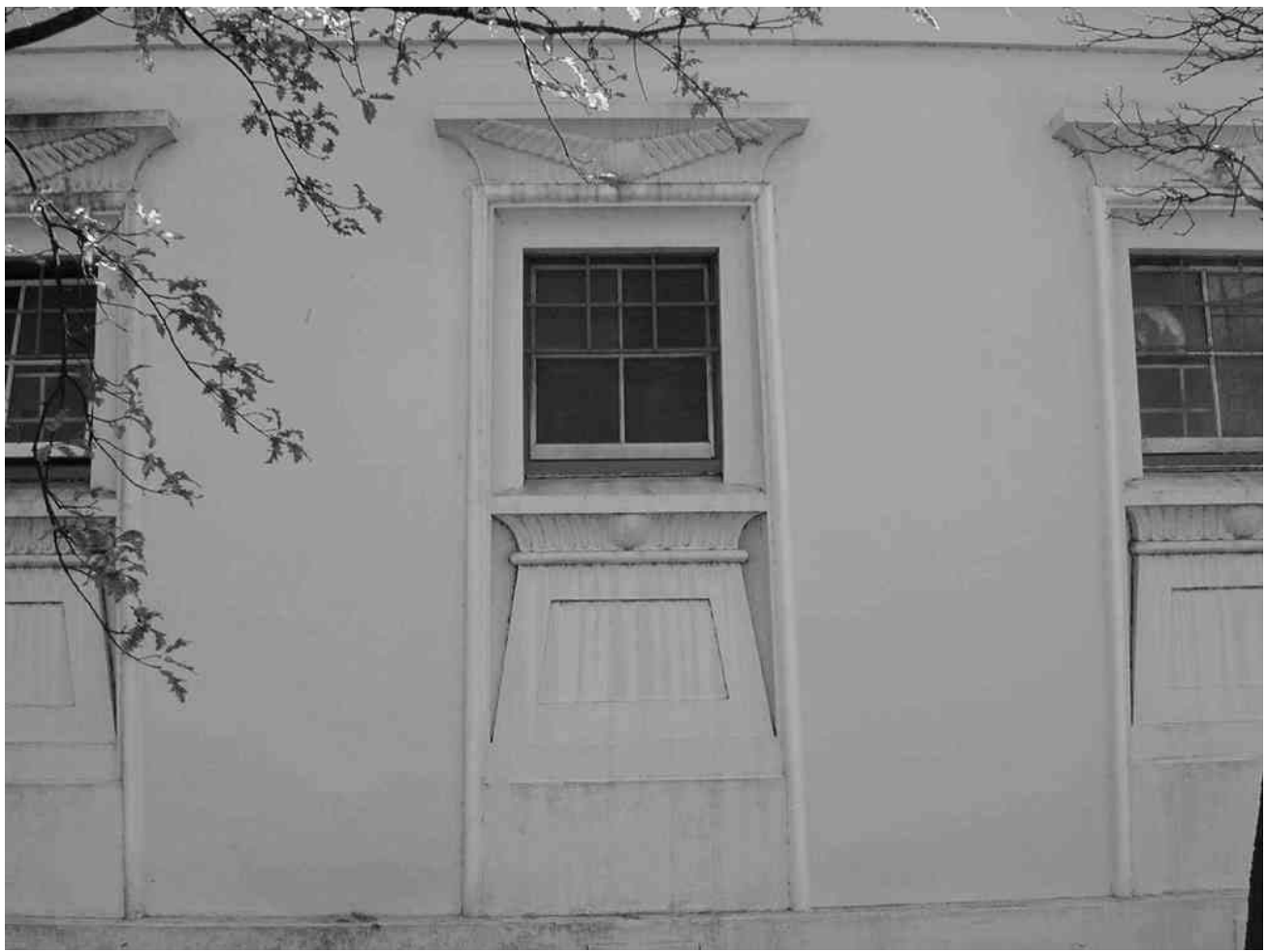

Fig. 2B: Egiptiese gebou, Universiteit van Kaapstad: piloon en sonsimbole 


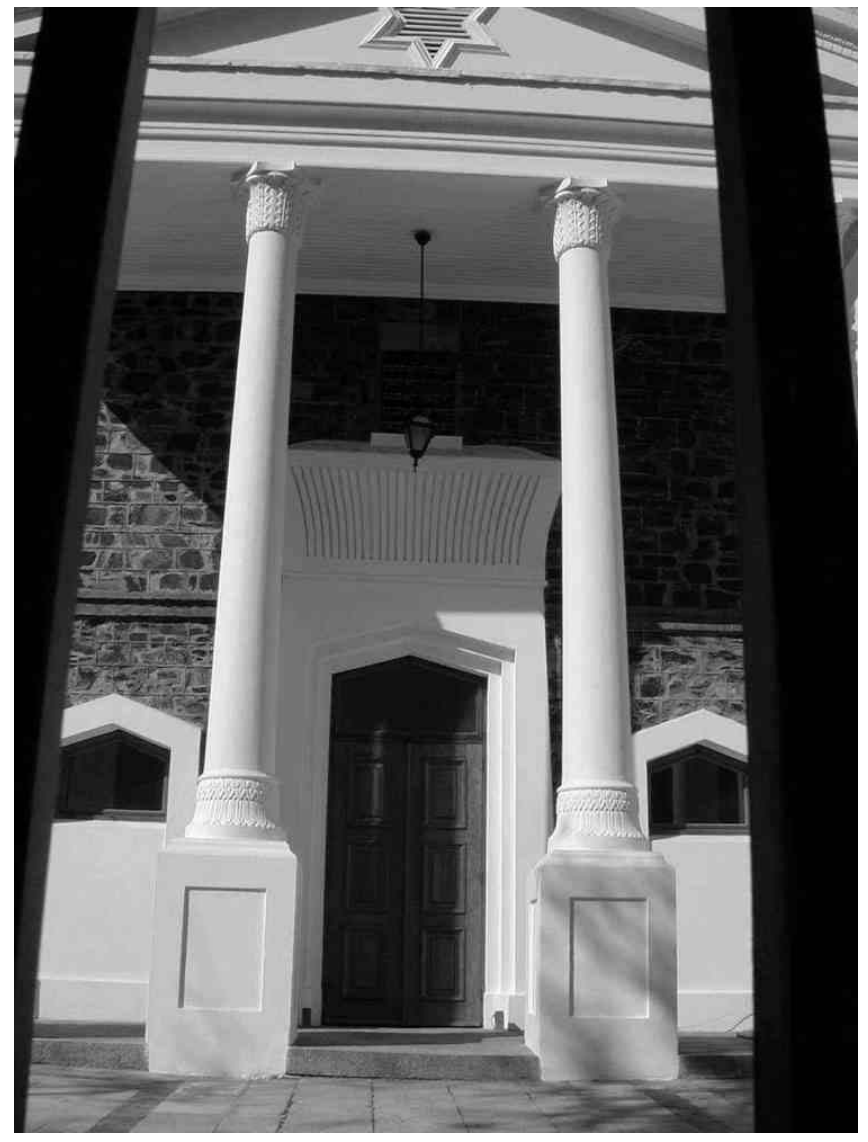

Fig. 3: Kaapse Tuine: sinagoge met pilare en cavetto corniche

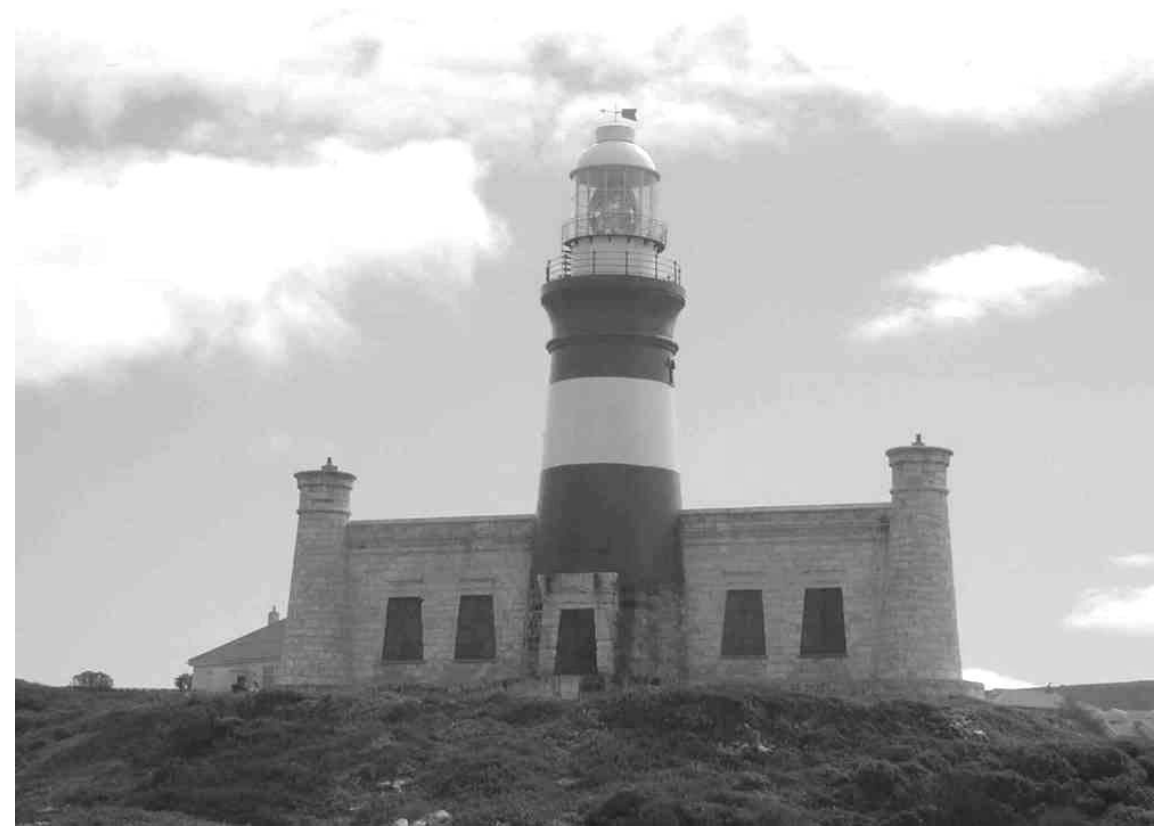

Fig. 4A: L'Agulhas vuurtoring 
CORNELIUS

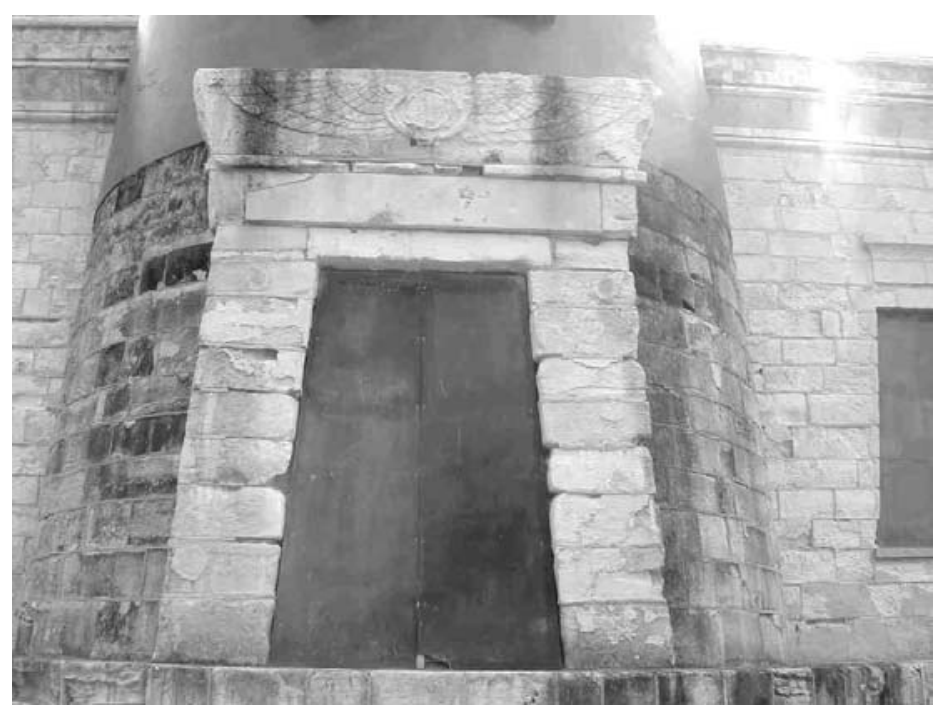

Fig. 4B: L'Agulhas vuurtoring: ingang met piloon en gevleuelde sonskyf

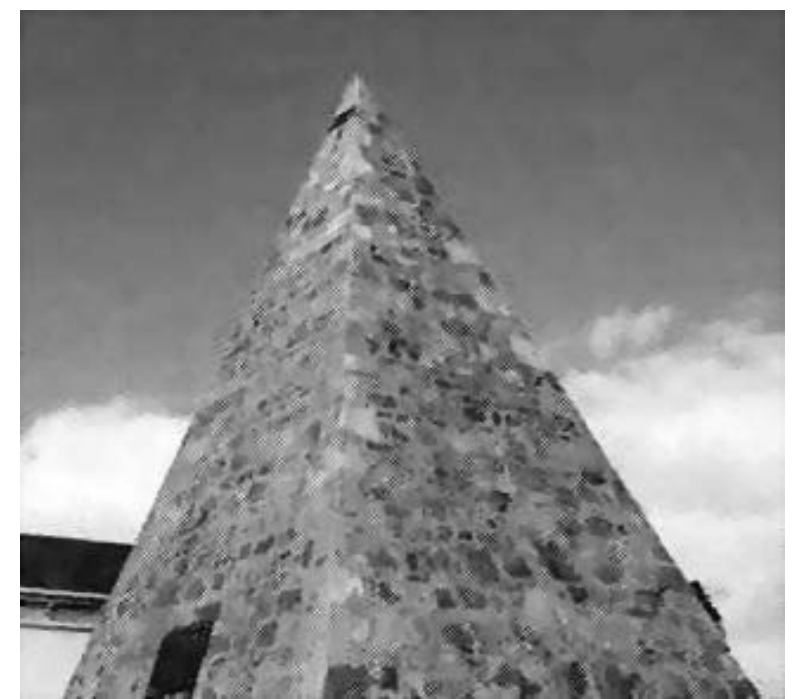

Fig. 5: Port Elizabeth: Donkinpiramide

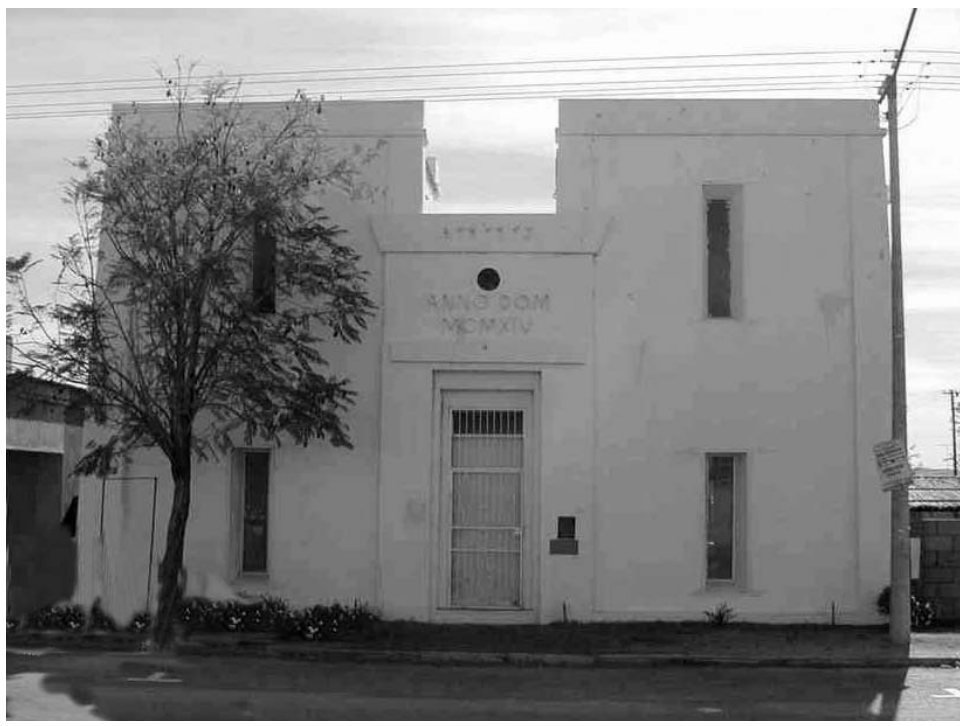

Fig. 6: Kakamas: Transformatorgebou 


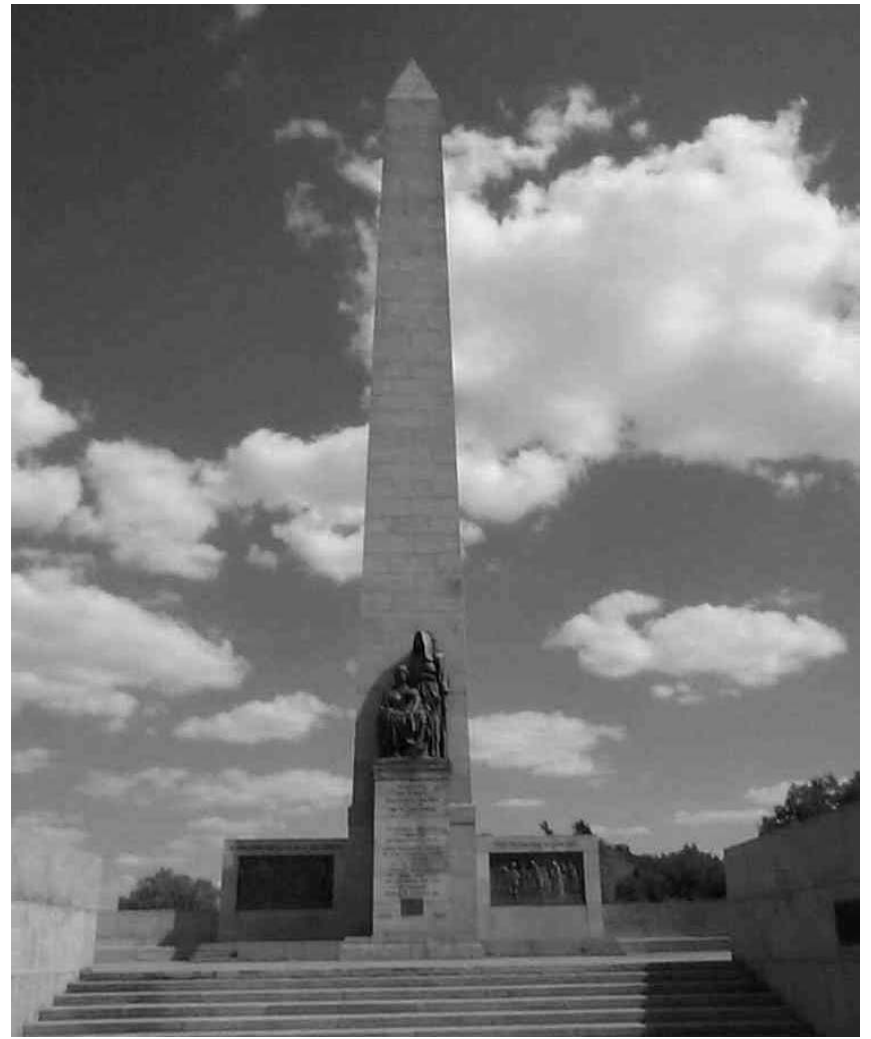

Fig. 7A: Bloemfontein: obelisk by Vrouemonument

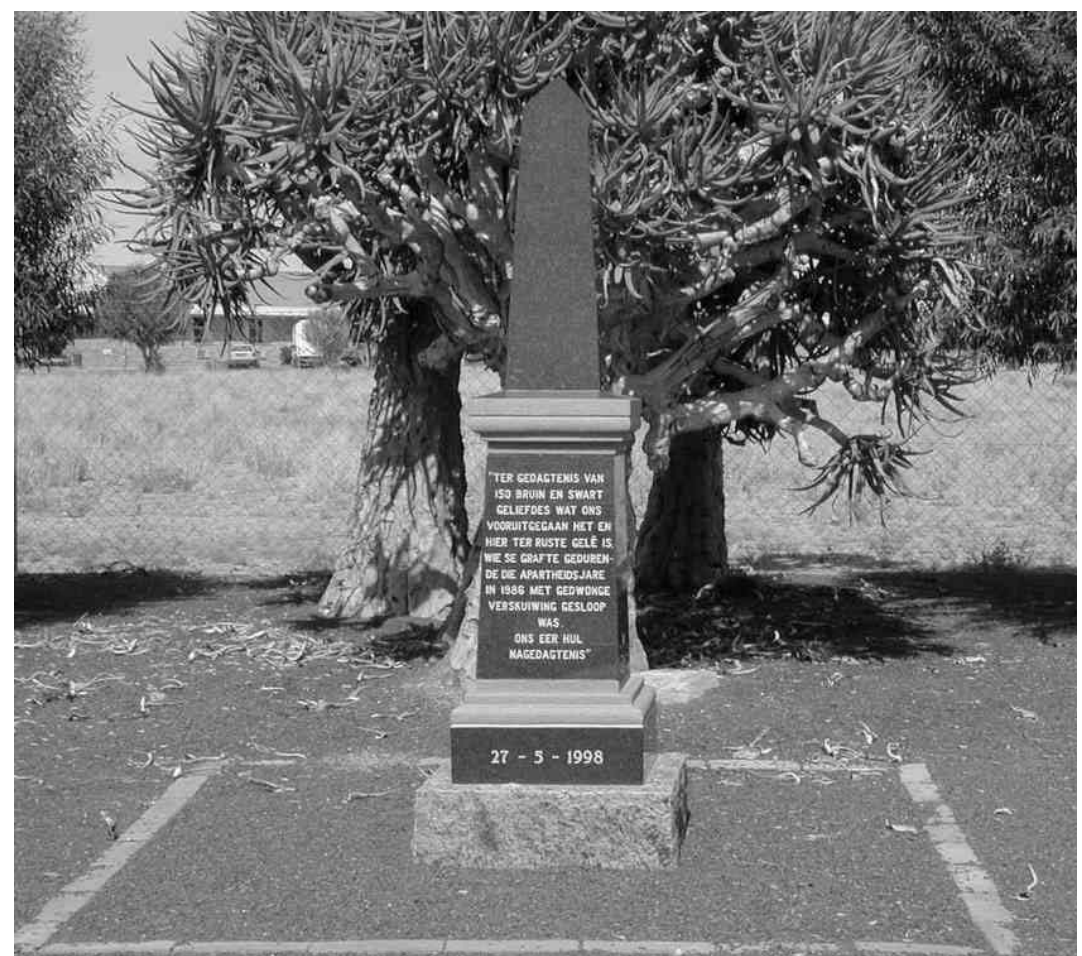

Fig. 7B: Kakamas: obelisk 